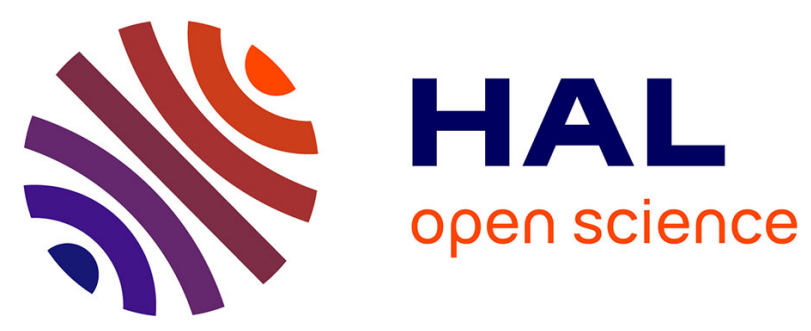

\title{
Effects of azaperone and haloperidol on the stress response of drive-net captured Iberian ibexes ()
}

Gregorio Mentaberre, Jorge Ramón López-Olvera, Encarnación Casas-Díaz, Laura Fernández-Sirera, Ignasi Marco, Santiago Lavín

\section{To cite this version:}

Gregorio Mentaberre, Jorge Ramón López-Olvera, Encarnación Casas-Díaz, Laura Fernández-Sirera, Ignasi Marco, et al.. Effects of azaperone and haloperidol on the stress response of drive-net captured Iberian ibexes (). European Journal of Wildlife Research, 2010, 56 (5), pp.757-764. 10.1007/s10344010-0371-3 . hal-00581870

\section{HAL Id: hal-00581870 \\ https://hal.science/hal-00581870}

Submitted on 1 Apr 2011

HAL is a multi-disciplinary open access archive for the deposit and dissemination of scientific research documents, whether they are published or not. The documents may come from teaching and research institutions in France or abroad, or from public or private research centers.
L'archive ouverte pluridisciplinaire HAL, est destinée au dépôt et à la diffusion de documents scientifiques de niveau recherche, publiés ou non, émanant des établissements d'enseignement et de recherche français ou étrangers, des laboratoires publics ou privés. 


\title{
Effects of azaperone and haloperidol on the stress response of drive-net captured Iberian ibexes (Capra pyrenaica)
}

\author{
Gregorio Mentaberre • Jorge Ramón López-Olvera • \\ Encarnación Casas-Díaz • Laura Fernández-Sirera • \\ Ignasi Marco • Santiago Lavín
}

Received: 1 September 2009 /Revised: 1 February 2010/Accepted: 24 February 2010/Published online: 1 April 2010

(C) Springer-Verlag 2010

\begin{abstract}
The physical capture of wild ungulates is performed for different purposes when anesthesia in field conditions is not possible or advisable. The use of tranquilizers may contribute to improved welfare of captured animals. This study aimed to evaluate the effect of azaperone and haloperidol on the stress response of Iberian ibex (Capra pyrenaica) through the evaluation of physiological, hematological, and serum biochemical parameters. Thirty-five Iberian ibexes were drive-net captured and randomly injected with azaperone $(0.52 \pm$ $0.07 \mathrm{mg} / \mathrm{kg}$ intramuscularly (IM); $n=10)$, haloperidol $(0.17 \pm$ $0.04 \mathrm{mg} / \mathrm{kg} \mathrm{IM} ; n=10)$, or saline $(0.5 \mathrm{~mL} \mathrm{IM} ; n=15)$ and physically restrained for $3 \mathrm{~h}$. The variability of heart rate was lower in the azaperone-treated ibexes, suggesting a calming effect, and erythrocyte and biochemical parameters indicated vasodilation, splenic sequestration, hemodilution, improvement of renal perfusion, and a protective effect on muscle as a result of smooth muscle relaxation induced by azaperone. Haloperidol showed poorer results, maybe due to insufficient dosage. These results support the suitability of using azaperone in capture operations of Iberian ibex in order to reduce stress and prevent its adverse effects.
\end{abstract}

Keywords Iberian ibex · Haloperidol · Azaperone · Drive-net capture $\cdot$ Acute stress

Communicated by C. Gortázar

G. Mentaberre $(\bowtie) \cdot J$. R. López-Olvera $\cdot$ E. Casas-Díaz •

L. Fernández-Sirera $\cdot$ I. Marco $\cdot \mathrm{S}$. Lavín

Servei d'Ecopatologia de Fauna Salvatge, Facultat de Veterinària,

Universitat Autònoma de Barcelona,

08193 Bellaterra, Spain

e-mail: gregorio.mentaberres@uab.cat

\section{Introduction}

The capture of Iberian ibex (Capra pyrenaica), an expanding although "near threatened" species (IUCN Caprinae Specialist Group 2007), is performed for translocation, population restocking, or scientific purposes. The resulting stress response is highly variable depending on the species and the capture method used (Kock et al. 1987). Drive nets have proved to be suitable for routine capture operations of Iberian ibex (Casas-Díaz et al. 2008a) and other species of wild ungulates (Kenny et al. 2008; López-Olvera et al. 2007; Montané et al. 2003). Nevertheless, keeping stress to a minimum is necessary to improve animal welfare in terms of reducing anxiety and lessen mortality derived of the physiological negative effects of stress (Spraker 1993).

Catecholamines and corticosteroids released during the stress response, together with prolonged exertion, induce changes in hematological, serum biochemical, and physiological parameters (Guyton and Hall 2000). Those parameters, or a combination of them, have been widely used as indicators of stress in wild ungulates (Franzmann and Thorne 1970; Hattingh et al. 1990; Horalek and Jones 1993; Hyvärinen et al. 1976; Kock et al. 1987; Marco et al. 1997; Mautz et al. 1980; Rehbinder and Edqvist 1981; Waas et al. 1999).

Animal welfare is improved when tranquilizers are used appropriately (Ebedes and Raath 1999). The usefulness of acepromazine (ACP) to reduce stress in Iberian ibex has been demonstrated in previous studies (Casas-Díaz et al. 2008b). Haloperidol and azaperone (butyrophenones family) are short-acting neuroleptics which induce central dopaminergic and peripheral adrenergic blockade (Booth 1988; Plumb 2002). Both have been described as effective sedatives in small- and medium-sized antelope and deer 
species (haloperidol: 0.06-0.45 mg/kg; azaperone: 0.05$2.83 \mathrm{mg} / \mathrm{kg}$ ) (Arnemo et al. 1993; Ebedes and Raath 1999; Read and McCorkell 2002; Swan 1993).

In order to find other tranquilizers useful for the treatment of stress in the Iberian ibex, we evaluated the effect of azaperone and haloperidol on stress indicators of drive-net captured individuals.

\section{Materials and methods}

Thirty-five free-ranging Iberian ibexes (age range: 111 years; $4.1 \pm 2.51$ years [mean \pm standard deviation]; sex: 11 males and 24 females), were captured with $10 \times 10 \mathrm{~cm}$ mesh drive nets (Ziboni Ornitecnica, Bergamo, Italy), as described by López-Olvera et al. (2009). Capture operations $(n=12$; March 2005-November 2007) were performed at the National Game Reserve of Puertos de Tortosa y Beceite $\left(40^{\circ} 50^{\prime} \mathrm{N}, 0^{\circ} 30^{\prime} \mathrm{E}\right)$, in Northwest Spain, and in the early morning, to avoid heat, and keep environmental conditions consistent.

Once trapped, ibexes were physically restrained, blindfolded, and held in a $4 \times 4 \mathrm{~cm}$ mesh sack nets (Ziboni Ornitecnica, Bergamo, Italy) until released $3 \mathrm{~h}$ later. Blood samples were collected (disposable $10-\mathrm{mL}$ syringes with $21-\mathrm{G} \times 1$ in needles) from the jugular vein at capture (time 0 ) and each hour thereafter for $3 \mathrm{~h}$ (times 1, 2, and 3). Two milliliters of each sample were placed in commercial tubes with anticoagulant (ethylenediaminetetraacetic acid- $\mathrm{k}_{3}$ ) and the remainder was placed in tubes for serum collection, allowed to clot at room temperature, and centrifuged at $1,800 \mathrm{G}$. Blood samples were conserved and transported at $4^{\circ} \mathrm{C}$ until analysis, 2 to $5 \mathrm{~h}$ after collection. Serum was frozen at $-20^{\circ} \mathrm{C}$ until analysis for a maximum period of 2 months. After collection of the first blood sample, random injections of azaperone $-n=10$; two males and eight females - $(0.52 \pm 0.07 \mathrm{mg} / \mathrm{kg}$ [mean \pm standard deviation] $)$ (Stressnil; Janssen-Esteve Laboratories, Barcelona, Spain), haloperidol $-n=10 ; 4$ males and 6 females- $(0.17 \pm$ $0.04 \mathrm{mg} / \mathrm{kg}$ ) (Haloperidol; Kern Pharma-Esteve Laboratories, Barcelona, Spain) or saline $-n=15$; five males and ten females - $(0.5 \mathrm{~mL})$ were administered intramuscularly (IM) in the hamstring muscle groups (semimembranous, semitendinous, and biceps femoris). Dosages intended for use were similar to those previously reported in other species of wild ungulates $(0.2 \mathrm{mg} / \mathrm{kg}$ of haloperidol; $0.5-1 \mathrm{mg} / \mathrm{kg}$ of azaperone). Since doses were previously filled in syringes for standard weights of the species according to sex and age class, the resulting dosages were obtained dividing the injected dose by the real weight of each animal. Ibexes were kept in a quiet site close to the capture site until the end of the study ( $3 \mathrm{~h}$ altogether, from capture).
Ibexes were fitted with heart rate (Polar S710i; Polar Electro, Kempele, Finland) and body temperature (Mätman datalogger, Chipsobits Eltex AB, Almut, Sweden) recording devices, as previously described (López-Olvera et al. 2006), which is approximately 20-30 min after restraint and treatment administration. Both heart rate and rectal temperature were recorded at 60 -s intervals until release and the mean values every 5-min calculated for statistical analysis. The erythrocyte and leukocyte counts, and the hemoglobin concentration, were determined by means of an automated laser analyzer (Advia 120, Bayer, Fernwald, Germany). The packed cell volume (PCV) was measured using a microhematocrit centrifuge (Hematospin 1400, Hawksley, Lancing, England) at 14,000 G for 6 min. The differential leukocyte count was performed by identifying 200 leukocytes on blood smears stained with a commercial Diff-Quick-like stain (Química Clínica Aplicada, Amposta, Spain). Biochemical parameters were determined by means of an automatic analyzer (Olympus AU400, Olympus, Tokyo, Japan), except for cortisol, which was analyzed with a commercial ELISA kit (EIA-1887, DRG Instruments, Marburg, Germany).

Repeated measures analysis of variance was used to detect significant differences by means of the PROC MIXED procedure of SAS System for Windows, V9.1 (SAS Institute, Cary, NC, USA). The main factor was treatment (azaperone, haloperidol, or saline), and the repeated factor was time. For each variable, sex, age, season, and interactions between these factors were considered in the model. When statistical differences between treatment groups at time 0 were obtained, values were expressed as a time 0 ratio. Estimated marginal means (command least-square means-LS MEANS - of SAS) were used due to the unbalanced distribution of animals between groups. In all cases, the minimum accepted significance level was $P<0.05$.

This study was approved by the Animal Welfare Committee of the Universitat Autònoma de Barcelona.

\section{Results}

Animals captured per operation ranged from zero to a maximum of eight animals $(2.45 \pm 2[$ mean \pm standard deviation]). Thirteen ibexes were captured in five capture events performed in spring and 22 in other seven capture events performed in autumn.

Both heart rate and rectal temperature decreased over time in all three groups (Fig. 1). However, stabilization of heart rate (i.e., lack of significant differences between two consecutive means) occurred earlier in the control ibexes (60 min after beginning of monitoring) than in the ibexes treated with haloperidol $(70 \mathrm{~min})$. Heart rate record did not 

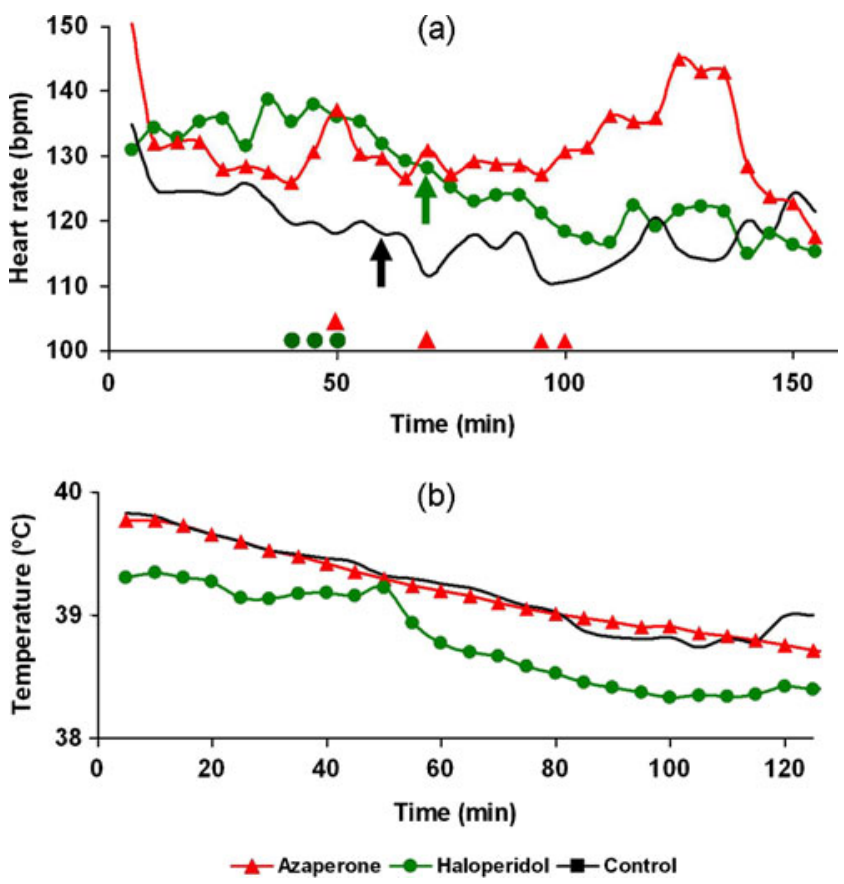

Fig. 1 Mean heart rate (A) and rectal temperature (B) of the captured ibex. The arrows indicate stabilization of the control and the haloperidol-treated groups, respectively; the dots and triangles in the $x$ axis indicate significant differences $(P<0.05)$ between the haloperidol-treated ibexes and the controls and between the azaperone-treated and the control ones, respectively

stabilize in the azaperone group. The azaperone-treated ibexes displayed significantly higher values for this parameter than the controls at min 50, 70, and from 95 to 100. The haloperidol-treated ibexes also displayed higher values than the controls from min 40 to 50 . On the other hand, individual and interindividual variability of heart rate was significantly lower in the azaperone-treated animals $(11.81 \% \pm 2.74 \%$ and $15.91 \% \pm 5.44 \%$ [mean \pm standard deviation]) than in the controls $(15.57 \% \pm 4.11 \%$ and $17.82 \% \pm 5.69 \%)$; in the haloperidol group $(13.18 \% \pm 5.68 \%$ and $17 \% \pm 5.45 \%$ ), these coefficients did not significantly differ from those in the other groups. No treatment differences in body temperature were observed between groups.

The erythrocyte count, PCV, hemoglobin, and total protein concentrations decreased over time in all groups, the stronger decrease being observed in the azaperonetreated ibexes, which also displayed lower values for these parameters than the control from time 1 onward. The haloperidol group did not show treatment differences in these parameters when compared to the control and azaperone-treated groups (Fig. 2). A transient significant decrease of WBC count was observed in both the treated groups at times 1 and 2 .
Serum lactate and potassium concentrations decreased more in both the treated groups, serum creatinine concentration decreased only in the azaperone-treated animals, and serum urea concentration increased more in the control ibexes (Fig. 3). Serum activity of creatine kinase (CK) increased in both the control and the haloperidol groups, the stronger increase being observed in the untreated ibexes. The serum activity of alanine aminotransferase (ALT) increased only in the control ibexes. The azaperone group showed lower values of $\mathrm{CK}$ at the end of the study period and of ALT from time 1 onward. The lactate dehydrogenase (LDH) and the aspartate aminotransferase (AST) increased in all the ibexes, the stronger rise being observed in the control ones (Fig. 4).

The remaining parameters (serum cortisol, glucose, cholesterol, bilirubin, chloride and sodium concentrations, and alkaline phosphatise activity) did not show clear treatment differences. Significant differences according to sex, age, and season or their interactions were not detected.

\section{Discussion}

Stress caused by capture and handling in wild ungulates can be assessed by measuring changes in hematological, biochemical, and clinical parameters (Cross et al. 1988; Kock et al. 1987; Meyer et al. 2008; Waas et al. 1999; Williams and Thorne 1996). According to Hopster and Blokhuis (1994), heart rate is a good indicator of the status of the autonomic nervous system when confronted with stressors. Both stress response and the effect of tranquilizers in the treated ibexes had already started when monitoring of heart rate began. The higher records observed in both the treated groups in our study could be due to the reflex tachycardia secondary to hypotension caused by the tranquilizers (Plumb 2002), as previously reported in tranquilized deer (Diverio et al. 1996; Montané et al. 2002 and 2003). Nevertheless, it increases at capture due not only to catecholamines, but also to physical activity and handling of the animal, so that other authors suggest that heart rate variability (HRV) may be a better indicator of stress. HRV is a measure of the state of the autonomic nervous system function (competitive activity of sympathetic and parasympathetic branches) of the individual and of its capacity to respond to environmental demands (Golberger 1991; Porges 1985). The lower HRV in the azaperone-treated ibexes suggests a calming effect, which is not observed in the haloperidol-treated group. Therefore, although a low degree of sedation is described for butyrophenones (Plumb 2002), the cardiovascular effects of azaperone could partially mask its beneficial ones. An inappropriately low dose could be the reason for this result in the haloperidol-treated ibexes. In our study, heart rate 

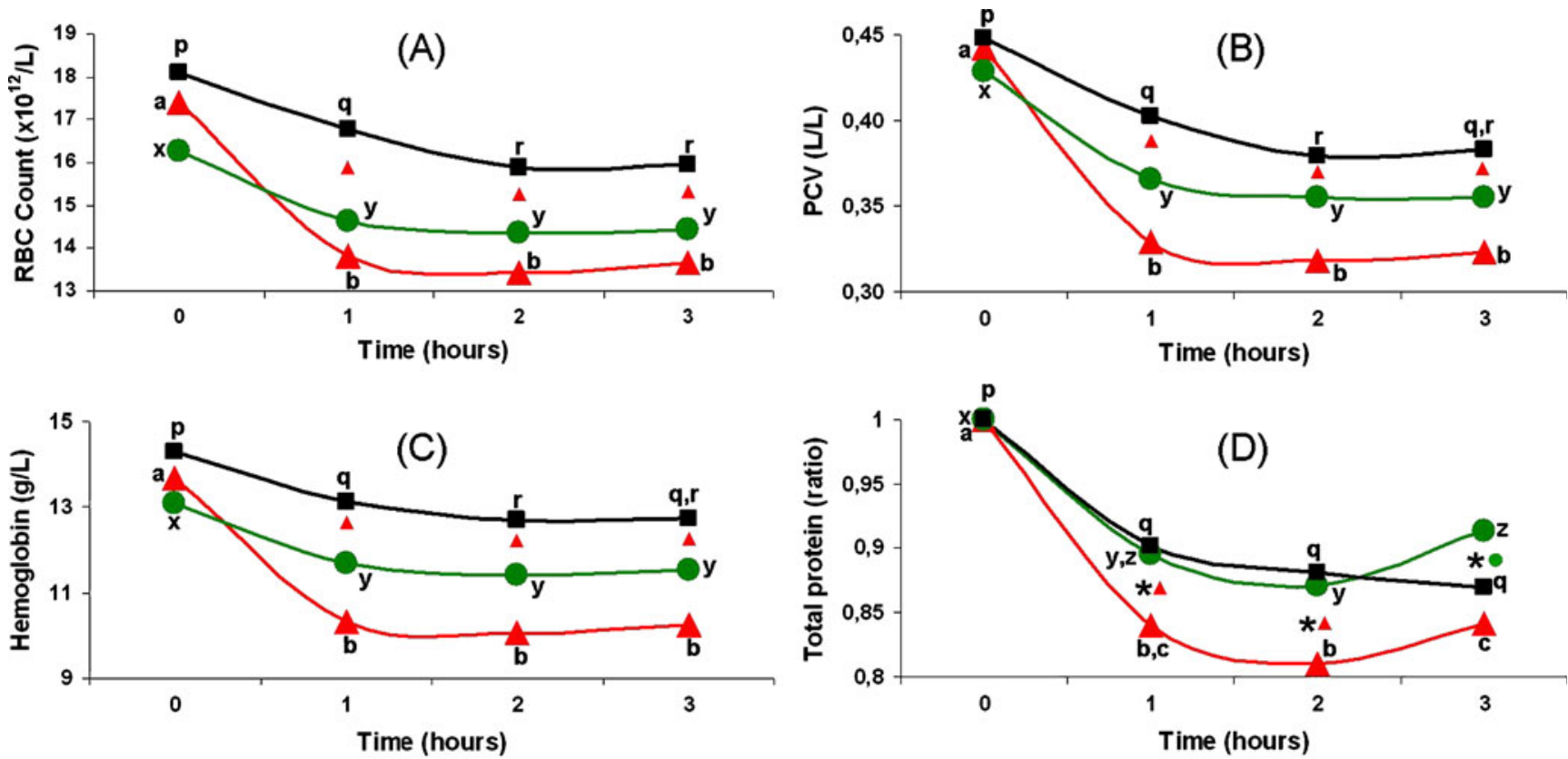

$\rightarrow$ Azaperone $-\longrightarrow$ Haloperidol $\rightarrow-$ Control

Fig. 2 Mean (A) red blood cell $(R B C)$ count, (B) packed cell volume $(P C V),(\mathbf{C})$ hemoglobin, and $(\mathbf{D})$ total protein concentrations of the captured ibex. The triangles indicate significant differences $(P<0.05)$ between the control and the azaperone-treated groups at each time; the dot indicates significant differences between the control and the haloperidol-treated groups; the asterisks indicate significant differences between both the treated groups. Different letters ( $a, b, c ; p, q, r$; $x, y, z)$ indicate significant differences $(P<0.05)$ between means within same treatment group along time
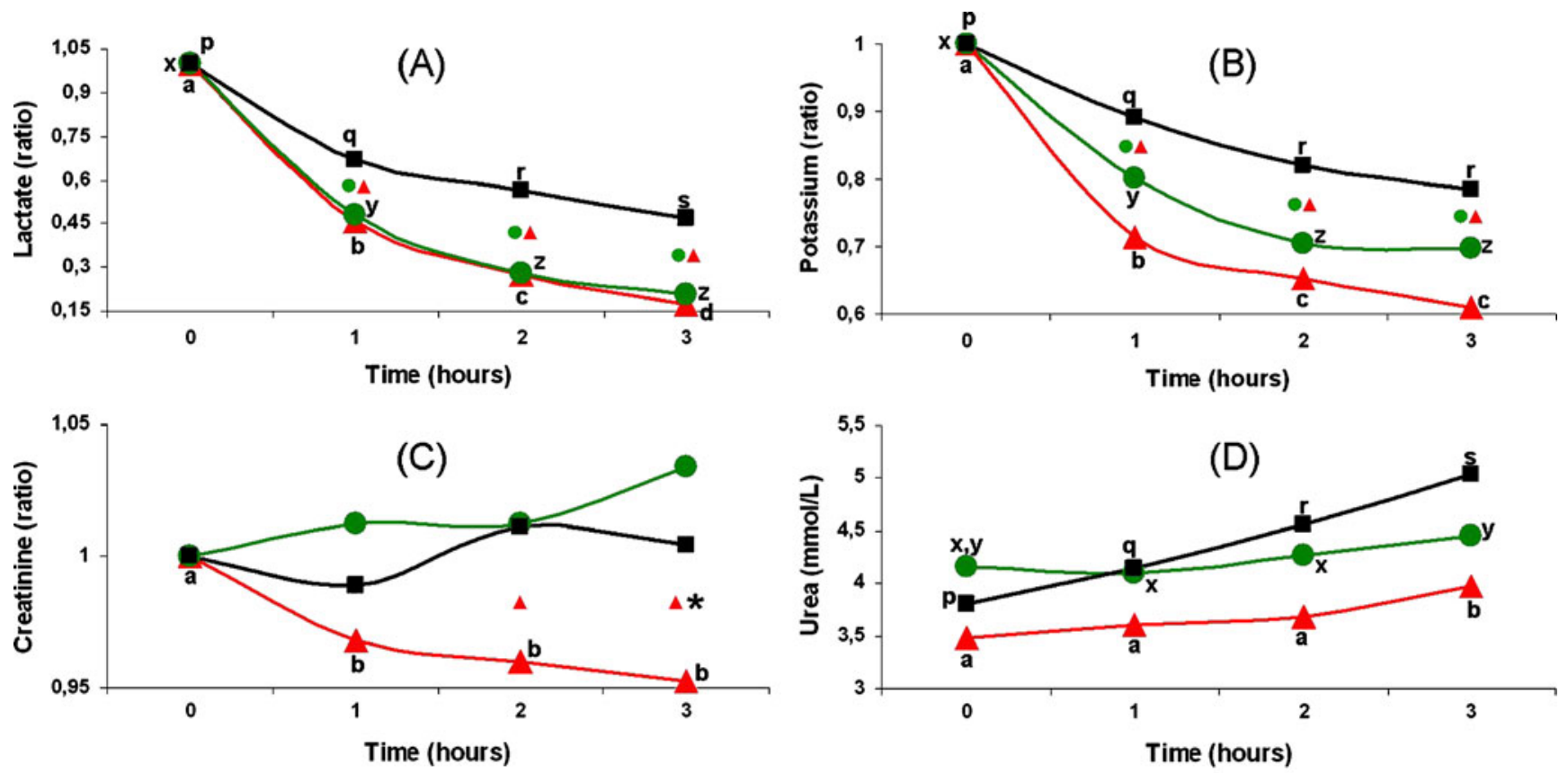

Azaperone $-\rightarrow$ Haloperidol $\rightarrow-$ Control

Fig. 3 Mean (A) serum lactate, (B) potassium, (C) creatinine, and (D) urea concentrations for the captured ibex. The triangles indicate significant differences $(P<0.05)$ between the control and the azaperone-treated groups at each time; the dots indicate significant differences between the control and the haloperidol-treated groups; the asterisk indicates significant differences between both the treated groups. Different letters $(a, b, c ; p, q, r ; x, y, z)$ indicate significant differences $(P<0.05)$ between means within the same treatment group along time 

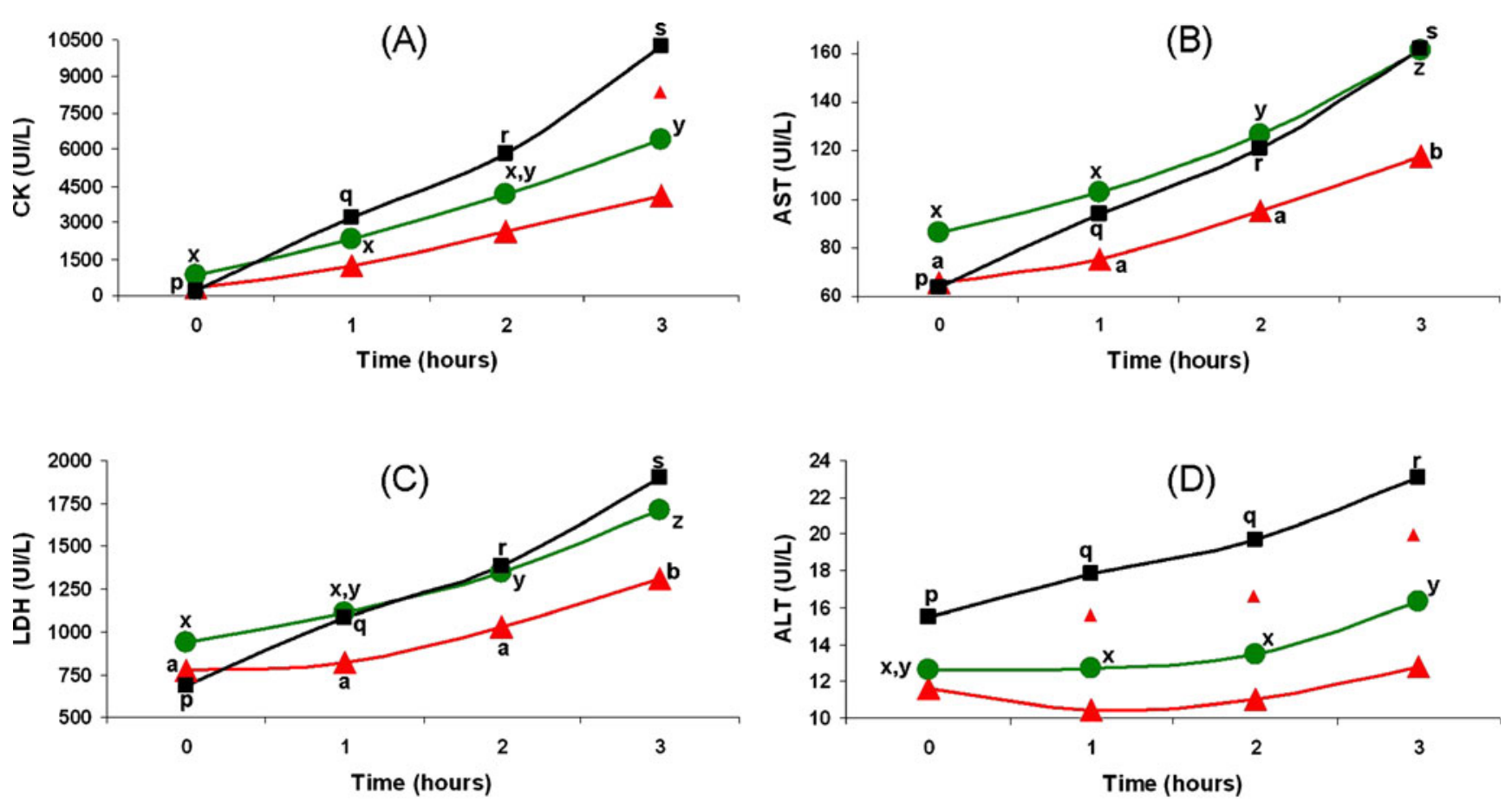

Fig. 4 Mean (A) creatine kinase (CK), (B) aspartate aminotransferase $(A S T),(\mathbf{C})$ alanine aminotransferase $(A L T)$, and (D) lactate dehydrogenase $(L D H)$ for the captured ibex. The triangles indicate significant differences $(P<0.05)$ between the control and the azaperone-treated groups at each time. Different letters $(a, b ; p, q, r, s ; x, y, z)$ indicate significant differences $(P<0.05)$ between means within same the treatment group along time

activity inherent to different capture methods (Meyer et al. 2008).

Catecholamines released during stress response stimulate $\alpha$-adrenergic receptors in the smooth muscle and cause splenic contraction and peripheral vasoconstriction (Ganong 2002). The decrease of erythrocyte count, PCV, hemoglobin, and total protein concentration observed in all three groups indicates a return to baseline values after reaching its maximum at capture. However, the drop was found to be more significant in the azaperone-treated animals, probably due to vasodilation and splenic sequestration of erythrocytes owing to splenic capsule relaxation caused by azaperone (Jain 1993). Hemodilution caused by the vasodilation could also explain the transient decrease observed in total protein concentration and in WBC count (Plumb 2002). Haloperidol succeeded in significantly decreasing these parameters at higher doses in drive-net captured chamois $(0.28 \pm$ $0.12 \mathrm{mg} / \mathrm{kg})$ and roe deer $(0.3 \pm 0.04 \mathrm{mg} / \mathrm{kg}$; Mentaberre et al. 1999a, b. Thus, the lack of treatment differences in these parameters in the haloperidol-treated ibexes vs. the controls could be due to insufficient dose $(0.17 \pm 0.04 \mathrm{mg} / \mathrm{kg})$. The leukogram followed the typical pattern of stress, with initial lymphocytic leukocytosis, and then corticosteroid-induced neutrophilia and lymphopenia (Jain 1993).

The lack of clear treatment differences in serum cortisol in our study indicates that it is not a good parameter to mia is caused predominantly by stress, more than by physical 
assess acute stress in Iberian ibex, as previously described in this (Casas-Díaz et al. 2008b) and other species of wild ungulates (Ingram et al. 1999; López-Olvera et al. 2007; Montané et al. 2003). The great interindividual differences in stress response, stress-induced changes in costicosteroid concentrations, and other factors such as the circadian, ultracircadian, and seasonal patterns of secretion are the main reasons argued to reject serum cortisol as an acute stress indicator (Guyton and Hall 2000; Rijnberg and Mol 1997).

Muscular activity and catecholamine-induced renal vasospasm cause an increase of serum creatinine and urea concentrations (Finco 1997; Kaneko 1997). Serum chloride, sodium, and potassium concentrations also increase due to decreased renal excretion and to release from working skeletal muscle (potassium; DiBartola and Autrain de Morais 2000; Gibert 1991). Higher values of serum lactate and lower values of serum total proteins, creatinine, and potassium concentrations have been reported in Spanish ibex in autumn (Casas-Díaz et al. 2008a). The higher percentage of ibexes captured in autumn in the azaperone group (eight out of ten) and in the haloperidol group (six out of ten) when compared to the controls (eight out of 15) in our study could explain the differences between groups found in these parameters at time 0 . Since no differences among groups were observed in serum chloride and sodium trends, the lower values of serum urea and potassium concentrations in both treated groups and of serum creatinine concentration in the azaperone-treated group are more probably related to the vasodilatory effect of tranquilizers, mainly azaperone, at the muscular level, rather than to improved renal perfusion. Vasodilation prevents potassium leakage secondary to muscular damage, thus decreasing the risk of shock, ventricular fibrillation, and even death (Guyton and Hall 2000).

When muscles move, blood flow decreases as muscle contracts because of the contraction of the vessels and increases during relaxation, which is called the muscle pump (Guyton and Hall 2000). The muscle pump is active when the animal is running but it is inactive when it is immobilized; thus, muscles of frightened and restrained animals are in a relatively isotonic state of contraction, which hinders blood flow into muscles. Serum CK, AST, $\mathrm{LDH}$, and ALT activities, as well as serum lactate concentration, increase due to increased muscle-cell permeability, damage related to poor tissue perfusion, decreased heat dissipation, and hypoxia induced by catecholamines. These conditions may occur in capture-stressed wild ungulates and in those suffering from capture myopathy (Vassart et al. 1992). Serum lactate concentration is a good predictor of muscular hypoxia and fatigue, main factors of the pathophysiology of capture myopathy (Spraker 1993), and CK and AST are the most sensitive, specific, and persistent indicators of muscular damage and, therefore, good predictors of capture myopathy too (Williams and Thorne 1996). Muscular enzymes increased only (ALT) or more (CK, LDH, and AST) in the control group, which displayed significantly higher values of CK and ALT at the end of the study period. Serum lactate concentration decreased after capture in all three groups, probably indicating a return to baseline values, as previously reported for wild ungulates (López-Olvera et al. 2007; Marco et al. 1997; Montané et al. 2003). However, lower values and stronger decrease were observed in both treated groups. These results indicate that both azaperone and haloperidol exert a protective effect against muscle damage, thus being useful to prevent capture myopathy. These two tranquilizers may yield this beneficial effect by blocking the $\alpha$-adrenergic receptors or by stimulating the $\beta_{2}$-adrenergic receptors and inducing vasodilation in striated muscle arterioles and, thus, increasing muscle blood flow, improving the oxygenation, and decreasing the anaerobic metabolism (Booth 1988; Guyton and Hall 2000).

In the present study, azaperone succeed to decrease erythrocyte parameters and creatinine whereas haloperidol did not, when compared to the control ibexes. However, similar effects were observed both for azaperone and haloperidol in muscular enzymes, lactate, urea, and potassium, the milder effects being observed in the haloperidol-treated animals. Since both tranquilizers belong to the butyrophenones family, similar action mechanisms are expected to take place. Thus, the more moderate action of haloperidol could be due to insufficient dose. It is likely that the beneficial effects of butyrophenones are mainly due to the induced peripheral vasodilation, which has a protective effect against the muscular damage that can occur during stress episodes in wild animals, and therefore, against the pathogenesis of capture myopathy.

The results obtained support the suitability of using azaperone in capture operations of Iberian ibex in order to reduce the stress response and prevent its adverse effects, mainly at the muscular level. More studies would be advisable to assess the effects of haloperidol at higher doses in the Iberian ibex. In addition to the use of tranquilizers, other measures to minimize stress should be employed such as blindfolding animals, maintaining a quiet handling environment, minimizing handling, and avoiding environmental conditions that promote hyperthermia.

Acknowledgments We are grateful to the staff of the National Game Reserve of Tortosa i Beseit, especially to its former director, Mr. Jordi Romeva, and to the Cos d'Agents Rurals (Rangers brigade) of Catalonia for their invaluable collaboration in facilitating and capturing the animals. This research has been supported as research project CGL2004-00330/BOS of the Comision Interministerial de Ciencia y Tecnología (CICYT). A native English-speaking instructor at the Universitat Autònoma de Barcelona provided editorial assistance. The experiments in this study comply with the current Spanish laws. 


\section{References}

Arnemo JM, Negard T, Soli NE (1993) Deer farming in Norway. A review of the currently available drugs that can be used for immobilization, pain relief and anaesthesia. Norsk-Veterinaertidsskrift 105:517-521

Bakken M, Moe RO, Smith AJ, Selle GME (1999) Effects of environmental stressors on deep body temperature and activity levels in silver fox vixens (Vulpes vulpes). Appl Anim Behav Sci 64:141-151

Booth NH (1988) Psychotropic agents. In: Booth NH, McDonald LE (eds) Veterinary pharmacology and therapeutics. Iowa State University Press, Ames, pp 321-345

Caprinae Specialist Group (2007) Capra pyrenaica. In: IUCN Red List of Threatened Species. Available via IUCN. http://www. iucnredlist.org. Accessed 5 March 2009

Casas-Díaz E (2007) Use of acepromazine for stress control in Spanish ibex (Capra pyrenaica) captured by drive-net. $\mathrm{PhD}$ Dissertation, Univertisat Autònoma de Barcelona

Casas-Díaz E, López-Olvera JR, Marco I, Mentaberre G, Lavín S (2008a) Hematologic and biochemical values for Spanish ibex (Capra pyrenaica) captured via drive-net and box-trap. J Wildl Dis 44(4):965-972

Casas-Díaz E, Marco I, López-Olvera JR, Mentaberre G, Lavín S (2008b) Use of acepromazine for stress control in Spanish ibex (Capra pyrenaica) captured by drive-net. Vet J doi:10.1016/j. tvj1.2008.11.003

Cross JP, Mackintosh CG, Griffin JFT (1988) Effect of physical restraint and xylazine sedation on hematological values in red deer (Cervus elaphus). Res Vet Sci 45:281-286

DiBartola SP, Autrain de Morais H (2000) Hypokalemia and hyperkalemia. In: DiBartola SP (ed) Fluid therapy in small animal practice. W.B. Saunders Company, Philadelphia, pp 83-107

Diverio S, Goddard PJ, Gordon IJ (1996) Use of long-acting neuroleptics to reduce the stress response to management practices in red deer. Appl Anim Behav Sci 49:83-88

Ebedes H, Raath JP (1999) Use of tranquilizers in wild herbivores. In: Fowler ME, Miller RE (eds) Zoo and wild animal medicine. Current therapy 4. W.B. Saunders Company, Philadelphia, pp 575-585

Fick L, Matthee A, Mitchell D, Fuller A (2006) The effect of bomahousing and long-acting tranquilizers on body temperature and food intake of blue wildebeest (Connochaetes taurinus). J Therm Biol 31:159-167

Fick L, Mitchell D, Fuller A (2007) Long-acting neuroleptics used in wildlife management do not impair thermoregulation or physical activity in goats (Capra hircus). Comp Biochem Physiol A 147:445-452

Finco DR (1997) Kidney function. In: Kaneko JJ, Harvey JW, Bruss ML (eds) Clinical biochemistry of domestic animals. Academic Press Inc, San Diego, pp 485-516

Franzmann AW, Thorne ET (1970) Physiologic values in wild bighorn sheep (Ovis canadensis canadensis) at capture, after handling, and after captivity. J Am Vet Med Assoc 157:647-650

Ganong WF (2002) Sistema nervioso autónomo. In: Ganong WF (ed) Fisiología Médica, 18th edn. El Manual Moderno SA, México DF, pp 245-252

Gibert P (1991) Conséquences de la capture et des manipulations sur la physiologie des ongulés sauvages. Incidence pathologique Bilan et conaissances B Mens Off Nation Chasse 161:31-40

Goldberger AL (1991) Is the normal heartbeat chaotic or homeostatic? News in Physiological Science 6:87-91

Guyton AC, Hall JE (2000) Textbook of medical physiology, 10th edn. W.B. Saunders Company, Philadelphia, pp 253-262

Hattingh J, Pitts NI, Ganhao MF, Carlston A (1990) Physiologicalresponse to manual restraint of wild Impala. J Exp Zool 253:47-50
Hopster H, Blokhuis HJ (1994) Validation of a heart-rate monitor for measuring stress-response in dairy-cows. Can J Anim Sci 74:465-474

Horalek G, Jones AR (1993) The heart rate of farmed red deer during and after transportation. Appl Anim Behav Sci 38:76

Hyvärinen H, Helle T, Nieminen M, Vayrynen P, Vayrynen R (1976) Some effects of handling reindeer during gatherings on composition of their blood. Anim Prod 22:105-114

Ingram JR, Crockford JN, Matthews LR (1999) Ultradian, circadian and seasonal rhythms in cortisol secretion and adrenal responsiveness to ACTH and yarding in unrestrained red deer (Cervus elaphus) stags. J Endocrinol 162:289-300

Jain NC (1993) Essentials of veterinary hematology. Lea and Febiger, Philadelphia

Kaneko JJ (1997) Serum proteins and disproteinemias. In: Kaneko JJ, Harvey JW, Bruss ML (eds) Clinical biochemistry of domestic animals. Academic Press Inc, San Diego, pp 45-81

Kenny D, DeNicola A, Amgalanbaatar S, Namshir Z, Wingard G, Reading R (2008) Successful field capture techniques for free-ranging Argali sheep (Ovis ammon) in Mongolia. Zoo Biol 27:137-144

Kock MD, Jessup DA, Clark RK, Franti CE (1987) Effects of capture on biological parameters in free-ranging bighorn sheep (Ovis canadensis) - evaluation of drop-net, drive-net, chemical immobilization and the net-gun. J Wildl Dis 23:641-651

López-Olvera JR, Marco I, Montané J, Lavin S (2006) Transport stress in Southern chamois (Rupicapra pyrenaica) and its modulation by acepromazine. Vet J 172:347-355

López-Olvera JR, Marco I, Montané J, Casas-Díaz E, Lavin S (2007) Effects of acepromazine on the stress response in Southern chamois (Rupicapra pyrenaica) captured by means of drive-nets. Can J Vet Res 71:41-51

López-Olvera JR, Marco I, Montané J, Casas-Díaz E, Mentaberre G, Lavín S (2009) Comparative evaluation of effort, capture and handling effects of drive nets to capture roe deer (Capreolus capreolus), Southern chamois (Rupicapra pyrenaica) and Spanish ibex (Capra pyrenaica). Eur J Wildl Res 55:193-202

Marco I, Viñas L, Velarde R, Pastor J, Lavin S (1997) Effects of capture and transport on blood parameters in free-ranging mouflon (Ovis ammon). J Zoo Wildl Med 28:428-433

Mautz WW, Seal US, Boardman CB (1980) Blood-serum analyses of chemically and physically restrained white-tailed deer. J Wildlife Manage 44:343-351

Mentaberre G, López-Olvera JR, Casas-Díaz E, Marco I, Lavín S (2009a) Haloperidol and azaperone in drive-net captured Southern chamois (Rupicapra pyrenaica). J Wildl Dis, Accepted on December, 2009

Mentaberre G, López-Olvera JR, Casas-Díaz E, Bach-Raich E, Marco I, Lavín S (2009b). Use of haloperidol and azaperone for stress control in roe deer (Capreolus capreolus) captured by means of drive-nets. Res Vet Sci. doi:10.1016/j.rvsc.2009.11.001

Meyer LC, Fick L, Matthee A, Mitchell D, Fuller A (2008) Hyperthermia in captured impala (Aepyceros melampus), a fright not flight response. J Wildl Dis 44(2):404-416

Montané J, Marco I, López-Olvera JR, Manteca X, Lavin S (2002) Transport stress in roe deer (Capreolus capreolus). Effect of a short-acting antipsychotic Anim Welfare 11:405-417

Montané J, Marco I, López-Olvera JR, Perpiñan D, Manteca X, Lavin S (2003) Effects of acepromazine on capture stress in roe deer (Capreolus capreolus). J Wildl Dis 39:375-386

Plumb DC (2002) Veterinary drug handbook, 4th edn. Iowa State University Press, Iowa

Porges SW (1985) Spontaneous oscillations in heart rate, potential index of stress. In: Moberg GP (ed) Animal stress. American Physiological Society, Bethesda, pp 97-112

Read MR, McCorkell RB (2002) Use of azaperone and zuclopenthixol acetate to facilitate translocation of white-tailed deer (Odocoileus virginianus). J Zoo Wildl Med 33:163-165 
Rehbinder C, Edqvist LE (1981) Influence of stress on some bloodconstituents in reindeer (Rangifer tarandus). Acta Vet Scand 22:480-492

Rijnberg AD, Mol JA (1997) Adrenocortical function. In: Kaneko JJ, Harvey JW, Bruss ML (eds) Clinical biochemistry of domestic animals. Academic Press Inc, San Diego, pp 485-516

Spraker TR (1993) Stress and capture myopathy. In: Fowler ME (ed) Zoo and wild animal medicine. Current therapy 3. W.B. Saunders, Philadelphia, pp 481-488

Swan GE (1993) Drugs used for the immobilization, capture and translocation of wild animals. In: McKenzie AE (ed) The capture and care manual. Capture, care, accommodation and transporta- tion of wild African animals. Wildlife Decision Support Services and The South African Veterinary Foundation, Pretoria, pp 264

Vassart M, Greth A, Anagariyah S, Mollet F (1992) Biochemical parameters following capture myopathy in one Arabian oryx (Oryx leucoryx). J Vet Med Sci 54:1233-1235

Waas JR, Ingram JR, Matthews LR (1999) Real-time physiological responses of red deer to translocations. J Wildlife Manage 63:11521162

Williams ES, Thorne ET (1996) Exertional myopathy (Capture myopathy). In: Fairbrother A, Locke LN, Hoff GL (eds) Noninfectious diseases of wildlife, 2nd edn. Iowa State University Press, Ames, pp 181-193 